\title{
Law Enforcement In Malaysian Securities Markets
}

\author{
Asmah Laili Yeon ${ }^{1}$, Faridahwati Samsuddin ${ }^{2}$ \\ ${ }^{1}$ (Associate Prof. Ph.D, School of Law, College of Law, Government and International Studies, \\ Universiti Utara Malaysia, Malaysia) \\ ${ }_{2}^{2}$ (Senior Lecturer Ph.D, School of Human Resource, College of Business, Universiti Utara Malaysia, Malaysia)
}

\begin{abstract}
The objective of this paper is to discuss issues of law enforcement in Malaysian Securities Markets. This survey was conducted among 107 principal and representative licensees registered with the Securities Commission of Malaysia. They consist of licensed dealers, investment advisers and fund managers. The majority of the respondents were capital markets and services representative licensees (CMSRL), while only 17 respondents were capital markets and services licensees. On a scale of one to five, respondents were found to be generally satisfied with the roles and responsibilities of enforcement bodies i.e. Securities Commission and Bursa Malaysia (mean of satisfaction $=3.660$ to 3.952). The study shows that there is a positive relationship between the views and attitudes of respondents towards the implementation of the legal philosophy by the enforcement bodies $(r=.524, r=.480)$. As the main enforcement agencies, Securities Commission and Bursa Malaysia should further enhance efforts to monitor and enforce the law of capital markets. In conclusion, this paper provides useful information in relation to factors contributing to non compliance of participants of the capital markets. The enforcement bodies can implement measures on how to curb the unethical behaviour by carrying out ethics training and introducing new rules and regulations for the industry.
\end{abstract}

Keywords - enforcement of law, investor protection, non-compliance, securities law, securities commission

\section{INTRODUCTION}

Capital and services markets provide a useful means to mobilize capital and harness economic interests in an efficient manner to drive innovation and growth. Toward this end, Malaysia has implemented various measures to make the capital markets more attractive and competitive in the form of Disclosure Based Regulations (DBR) through the Malaysian Capital Markets Master Plan 2000 - 2010. Recently, in 2011, the Securities Commission of Malaysia launched the second phase of the plan which focuses more on the regulatory challenges, growth, international standards and governance. In 2010, the Malaysian capital markets generated substantial income for the country. The equity market generated market RM1,275 billion, the bond market RM759 billion, the Islamic Capital Markets RM1,050 billion, the investment management RM377 billion, and the derivatives market RM43 billion (Securities Commission, 2011) [1]. The huge income generated by this industry is because of the capital and services market in Malaysia is well-regulated and this is recognized by the International Organization of Securities Commission (IOSCO, 2011) [2]. Further, Malaysia is the signatory to cross-border enforcement arrangements and known for high standards of regulation internationally. The MMOU has enhanced the SC's supervision and enforcement capabilities in dealing with cross-border market abuse, particularly in the area of financial fraud and insider trading, and has raised the level of overall investor protection in Malaysian market (Neetasha Rauf, 2012) [3]. The main regulator for the industry is the Malaysian Securities Commission which has a legal power under the Securities Commission Act 1993, whereas, the Bursa Malaysia is the main registered stock exchange in Malaysia and acting as a self regulator body for its members and recognized and given powers under the Capital Markets and Services Act 2007. They play important roles to enhance the securities markets and services in Malaysia. The Malaysian securities markets regulation has a comprehensive legal framework. But looking at the statistic of securities crimes in Malaysia, it shows increasing numbers in cases of securities crimes (Securities Commission, 2011) [4]. For example between 2004 and 2006, 2006 there were nine cases involving misconduct in securities transactions. The study by Asmah, Nurli, and Rohana (2002) [5] found that among the categories listed company involved in the non-compliance with the Listing Requirements of the KLSE (now known as Bursa Malaysia) is the manufacturing industry (24\%), construction (18.7\%), and securities market industry (14.7\%). Other industries, however, showed a relatively low percentage of non-compliance. Therefore, it is paramount important to discuss about the findings of the study in relation to law enforcement in Malaysian Securities Markets.

\section{LITERATURE REVIEW}

Malaysia has fully observed one of the 32 benchmarks (on accounting standards) and has largely observed nearly all of the benchmarks under the six categories of methodology ( $81 \%$ of 32 benchmarks) [6]. Since then, Malaysia continued to close the gaps on the remaining shortcomings, the most significant being amending the Companies Act 1965 (CA) to address gaps in related-party transactions, penalties for 
contravention by directors, private enforcement capacity of investors and disclosure; amending the listing requirements for stricter disclosures by listed companies; implementing measures to expand the role of the audit committee in line with international best practices; the Capital Market \& Services Act 2007 (CMSA) enhancing the effectiveness of regulatory oversight of the SC by empowering it to institute civil proceedings; and transforming GLCs into high-performing entities and upgrading of GLC boards

\section{Enforcement Bodies: Securities Commission and Bursa Malaysia}

The Securities Commission established on 1 March 1993 under the Securities Commission Act 1993.

The Commission is a self-funding statutory body with investigative and enforcement powers. It reports to the Minister of Finance and its accounts are tabled in Parliament annually. The SC's many regulatory functions include supervising exchanges, clearing houses and central depositories; registering authority for prospectuses of corporations other than unlisted recreational clubs; approving authority for corporate bond issues; regulating all matters relating to securities and futures contracts; regulating the take-over and mergers of companies ;regulating all matters relating to unit trust schemes; licensing and supervising all licensed persons; encouraging self-regulation; and ensuring proper conduct of market institutions and licensed persons.

Improving transparency and benchmarking against best international practices have been key factor in transforming the Malaysian capital market as an efficient source for raising longer-term funds to finance economic activity. Reflecting the importance accorded to meeting international standards, 43 of the 152 recommendations in the Capital Market Master plan that were released in 2002 were related to improving transparency and promoting higher standards of disclosures. To date, 37 of these 43 recommendations has been implemented (2010, Securities Commission) [7]. Further, the Securities Commission, as the competent regulatory authority for oversight of the capital market, has voluntarily undertaken independent assessments under the various standards set by the IMF/World Bank, and the International Organisation of Securities Commissions (IOSCO). The SC has also supported the move to comply with international best practices on accounting-related matters.

In relation to the implementation of Code of Corporate Governance, Malaysia voluntarily agreed to be assessed under the Corporate Governance Reports on the Observance of Standards and Codes (CG ROSC) by the World Bank in 2005, based on a methodology that is benchmarked against the internationally accepted OECD Principles of Corporate Governance. Malaysia has published the CG ROSC that was completed in 2005.

Malaysia has fully observed one of the 32 benchmarks (on accounting standards) and has largely observed nearly all of the benchmarks under the six categories of methodology ( $81 \%$ of 32 benchmarks). Since then, Malaysia continued to close the gaps on the remaining shortcomings, the most significant being amending the Companies Act 1965 (CA) [8] to address gaps in related-party transactions, penalties for contravention by directors, private enforcement capacity of investors and disclosure; amending the listing requirements for stricter disclosures by listed companies; implementing measures to expand the role of the audit committee in line with international best practices; the Capital Market \& Services Act 2007 (CMSA) enhancing the effectiveness of regulatory oversight of the $\mathrm{SC}$ by empowering it to institute civil proceedings; and transforming GLCs into high-performing entities and upgrading of GLC boards. In addition, the SC is also working closely with the respective Malaysian accounting boards to integrate accounting principles, with a commitment on full convergence with international accounting standards by 2012 .

As for Bursa Malaysia, in striving to build a market of quality and integrity, it is guided by regulatory principles to achieve goals in the aspect of (a) investor protection to remain intact, (b) high standards of business conduct by listed issuers and brokers and (c) efficient and effective (Bursa Malaysia, 2012) [9].

\section{Law, Principles, Rules and Policy}

The Capital Markets and Services Act 2007 (CMSA 2007) [10] states offences of securities crimes includes false trading, market rigging, market manipulation, fraudulent and misleading trading, dissemination of false trading and insider trading. Implementation of dual sanction, criminal and civil actions in combating securities crimes is seen as an effective strategy. These provisions are stated in the CMSA 2007 in Part V, Division 1, section 175 to 201.

According to the Bursa Malaysia in managing conflicts of interests with public interest, public interest and in particular the need for investor protection should prevail and the measures are separation of the regulatory functions from the commercial functions to ensure that these functions operate independently; and that business units within Bursa Malaysia are not in a position to influence any supervisory or regulatory decisions made by regulation.(Bursa Malaysia, 2012) [11].

As for Bursa Malaysia in regulating market misconduct, it has the Business Rules of Bursa Malaysia Securities Berhad (Market Misconduct) [12] where the key trading rules that market surveillance focuses on the following issues: (a) Rule 401.1(2) where participating Organisations (POs), Heads of Dealing (HD) and Dealer's Representative (DR) shall refrain themselves from engaging in, or be a party to, any unethical practices that may 
damage the confidence of investors and hamper the sound development of the stock market, (b) Rule 401.1(3)(a) and (b) where POs, HD and DR shall avoid, and shall not participate in any operation by others which might have the same result, any act or practice which might lead to a false or misleading appearance of active trading in any securities on the stock market of the Exchange or a false or misleading appearance with respect to the market for, or the price of, any such securities; or directly or indirectly be tantamount to stock market manipulations, (c) Rule 404.1(4) where a PO shall not allow any form of irregular and/or unhealthy practice to exist or prevail in its daily and professional business conduct, (d)Rule 404.1(7)(c) where every PO shall at all times maintain a proper supervisory programme and a system of internal controls which must take into account among others, the PO's operations and proper conduct of its business and (e) Rule 404.3(1)(a) and (c) where every PO and every DR shall at all times observe professional standard of integrity and fair dealing and conduct their business in a manner which contributes to the maintenance of a fair and orderly market. Further, market surveillance by the Bursa Malaysia is to ensure the market operates in a fair and orderly manner so as to promote efficient price discovery and investor protection. This is achieved through the conduct of dynamic and timely regulatory measures, the undertaking of real-time and post-trade monitoring and analysis of both equities and derivatives trading activities (Bursa Malaysia, 2012) [13]. The surveillance system is able to detect a wide range of possible market misconduct situations on real-time basis. The Bursa Malaysia Listing Requirements of Public Listed Companies (PLCs) is also one of legal document which regulates PLC in its business activities [14].

\section{RESEARCH METHODOLOGY}

To achieve the above objective, a survey was conducted among principal licensees registered with the Securities Commission of Malaysia. They consist of licensed dealers, investment advisers and fund managers. According to the official list issued by the Securities Commission, as at December 31, 2007, there were 37 licensed dealers(company), investment advisers (80 companies and 16 individuals), investment advisors (financial planner), (27 companies,and,14 individuals), and 80 fund managers (companies). For company licensee dealers, questionnaires were submitted to the Company Secretary and Compliance Officer. But for other licensees of a company status (e.g. investment advisors), questionnaires were given to the Company Secretary. License holders of an individual status, the questionnaires were personally handed to them.

Based on the distribution of questionnaires to the respondents, a total of 107 respondents had given their responses. Seventeen of the respondents are the Capital Markets and Services licensee while the remaining 90 respondents are the Capital Markets and Services Representative licensee (CMSRL). The respondents were asked to indicate their level of satisfaction or dissatisfaction on a five-point Likert scale ranging from $1^{\text {ce }}$ "Strongly dissatisfied" to 5" "Strongly satisfied", on a number of items on the performance of the implementation of capital market legal philosophy and the characteristics of public disclosure policy of Malaysian securities markets. With respect to legal philosophy, respondents were asked to indicate to what extent they were satisfied or not satisfied that the legal philosophy of capital market is able to respond to any changes in the financial field at different times and in appropriate ways, to ensure that capital markets continue to operate fairly and efficiently, and to assist economic development and growth, financial and business interests in the future, to name a few.

On the other hand, with respect to characteristics of public disclosure in Malaysia, respondents were asked to indicate whether they are satisfied or not satisfied that the public disclosure in Malaysia requires companies to make a public announcement of material information (e.g. income of the company, the Board of Directors), requires that the information disclosed in the prospectus the company must be simple and adequate for public knowledge, and enables and assists the public or potential investors to make the right choice and good value for their investment. The items of the instrument were assembled based on previous research and relevant Malaysian statutes, regulations and rules.

\section{RESULTS}

The discussion on this part will highlight results [15] of the following items; (i) license holders views on roles and responsibilities of enforcement bodies, (ii) policy and business rules of Bursa Malaysia and (iii) the relationship between the view and attitude of the respondent on the effective implementation of legal philosophy Securities Commission and Bursa Malaysia and (iv) discussion on selected cases where the SC had successfully brought these case to justice.

\section{License Holders views on Roles and Responsibilities of Enforcement Bodies}

Bursa Malaysia and Securities Commission Malaysia (SC) plays an important roles and in enforcement of securities law. Table 1 and 2 below shows the effectiveness of both bodies in carrying out their functions and responsibilities in the securities industry in the country. The findings show that respondents are generally satisfied with the effectiveness of the functions and responsibilities carried out by the two agencies. Table 1 describe that respondents are satisfied with the role played by the Securities Commission of Malaysia in terms 
of ensuring that the provisions of securities laws are complied with (mean $=3.915)$, monitoring and supervising the activities of any exchange, clearing and depository $(\min =3.906)$, and supervising all licensed holders under securities laws $($ mean $=3.952)$.

Table 1: Frequency (\%) Mean values for the level and effectiveness of the Securities Commission of Malaysia (SSM) in the Implementation Roles and Responsibilities

\begin{tabular}{|c|c|c|c|c|c|c|c|c|}
\hline No. & Item & NN & SD & $\mathrm{D}$ & $\mathrm{M}$ & $S$ & SS & Mean \\
\hline 1. & $\begin{array}{l}\text { Advise the Minister on all } \\
\text { matters } \begin{array}{r}\text { concerning } \\
\text { securities and futures } \\
\text { industry. }\end{array}\end{array}$ & 107 & - & 6.5 & 29.0 & 44.9 & 19.6 & 3.775 \\
\hline 2. & $\begin{array}{l}\text { To regulate all matters } \\
\text { relating to securities and } \\
\text { futures contracts. }\end{array}$ & 107 & - & 5.6 & 22.4 & 51.4 & 20.6 & 3.869 \\
\hline 3. & $\begin{array}{l}\text { To ensure that the } \\
\text { provisions of securities laws } \\
\text { are complied with. }\end{array}$ & 107 & - & 7.5 & 18.7 & 48.6 & 25.2 & 3.915 \\
\hline 4. & $\begin{array}{l}\text { Regulate the acquisition and } \\
\text { amalgamation } \\
\text { companies. }\end{array}$ & 107 & - & 6.5 & 22.4 & 54.2 & 16.8 & 3.813 \\
\hline 5. & $\begin{array}{l}\text { To regulate all matters } \\
\text { relating to unit } \\
\text { schemes. }\end{array}$ & 107 & - & 2.8 & 33.6 & 47.7 & 15.9 & 3.766 \\
\hline 6. & $\begin{array}{l}\text { Monitor and supervise the } \\
\text { activities of any exchange, } \\
\text { clearing house and central } \\
\text { depository. }\end{array}$ & 107 & .9 & 3.7 & 19.6 & 55.1 & 20.6 & 3.906 \\
\hline 7. & $\begin{array}{l}\text { Promote and encourage } \\
\text { good behavior among } \\
\text { members of the exchange, } \\
\text { clearing, depository and all } \\
\text { licensed persons. }\end{array}$ & 106 & 1.9 & 7.5 & 31.8 & 43.0 & 15.9 & 3.635 \\
\hline 8. & $\begin{array}{l}\text { Consider and } \\
\text { recommendations for law } \\
\text { reform in relation to } \\
\text { securities and futures } \\
\text { contracts. }\end{array}$ & 106 & 2.8 & 12.1 & 18.7 & 42.1 & 24.3 & 3.729 \\
\hline 9. & $\begin{array}{l}\text { Encourage and promote the } \\
\text { development of securities } \\
\text { markets and futures } \\
\text { contracts in Malaysia, } \\
\text { including research and } \\
\text { training related to it. }\end{array}$ & 106 & .9 & 6.6 & 33.0 & 44.3 & 15.1 & 3.660 \\
\hline 10. & $\begin{array}{l}\text { Licensing and supervising } \\
\text { all licensed persons under } \\
\text { the securities laws. } \\
\text { 10Dictionary } \\
\text { Bottom of Form }\end{array}$ & 106 & .9 & 6.6 & 17.9 & 45.3 & 29.2 & 3.952 \\
\hline 11. & $\begin{array}{l}\text { Develop and maintain the } \\
\text { integrity of all licensed } \\
\text { persons }\end{array}$ & 106 & - & 11.3 & 17.0 & 53.8 & 17.9 & 3.783 \\
\hline
\end{tabular}

From Table 2 below, the study found that respondents are generally satisfied with Bursa Malaysia's role in carrying out their duties and responsibilities as a self-regulator. This is in terms of protecting the public interest by providing protection to investors' needs (mean $=3.869$ ), and take appropriate action as provided in the Rules 
of Bursa Malaysia for the purpose of monitoring or ensuring compliance (mean $=3.841$ ). The respondents also satisfied with the role of Bursa Malaysia in ensuring if any interest required to be protected by any law relating to conflict with the interests of the corporation as aforesaid, then the public interest should prevail (mean = 3.719).

Table 2: Frequency (\%) Mean values for the level and effectiveness of the Bursa Malaysia (BM) in the Implementation Roles and Responsibilities as a Self-regulator

\begin{tabular}{|l|l|l|l|l|l|l|l|l|}
\hline No. & Item & N & SD & D & M & S & SS & Mean \\
\hline 1. & $\begin{array}{l}\text { Protecting the public interest by } \\
\text { providing protection to investors' } \\
\text { needs. }\end{array}$ & - & 4.7 & 19.6 & 59.8 & 15.9 & 3.869 \\
\hline 2. & $\begin{array}{l}\text { Ensure that if any interest } \\
\text { required to be protected by any } \\
\text { law relating to conflict with the } \\
\text { interests of the corporation as } \\
\text { aforesaid, then the public interest } \\
\text { should prevail. }\end{array}$ \\
\hline 3. & $\begin{array}{l}\text { Take appropriate action as } \\
\text { provided in the Rules of Bursa } \\
\text { Malaysia for the purpose of } \\
\text { monitoring or ensuring } \\
\text { compliance. }\end{array}$ & -9 & 7.5 & 24.3 & 53.3 & 14.0 & 3.719 \\
\hline
\end{tabular}

\section{Policy and Business Rules of Bursa Malaysia}

Respondents were also asked about the extent to which policies and regulations of Bursa Malaysia (BM) and comprehensive enough. Table 3 shows the findings of the study. Generally, respondents felt that the policies and regulations of Bursa Malaysia in terms of public dissemination of the policy (mean $=3.476$ ), immediate disclosure of material information $($ mean $=3654)$, and periodic disclosure $($ mean $=3.3523)$ is sufficient and comprehensive.

Table 3: Frequency (\%) and Mean Value of Any perception on the How the Policy and Rules of Bursa Malaysia Adequate and Comprehensive

\begin{tabular}{|c|c|c|c|c|c|c|c|c|}
\hline No. & Item & $\mathrm{N}$ & SD & $\mathrm{D}$ & Uncertain & A & SA & Mean \\
\hline 1. & $\begin{array}{l}\text { Corporate disclosure } \\
\text { policies are generally in the } \\
\text { Listing Requirements of } \\
\text { Public Listed Companies is } \\
\text { sufficient and } \\
\text { comprehensive. }\end{array}$ & 107 & - & 8.4 & 30.8 & 54.2 & 6.5 & 3.588 \\
\hline 2. & $\begin{array}{l}\text { Immediate disclosure of } \\
\text { policy information is } \\
\text { sufficient and } \\
\text { comprehensive material. }\end{array}$ & 107 & - & 9.3 & 23.4 & 59.8 & 7.5 & 3.654 \\
\hline 3. & $\begin{array}{l}\text { Public dissemination of the } \\
\text { policy as a whole is } \\
\text { sufficient } \\
\text { comprehensive. }\end{array}$ & 107 & .9 & 15.9 & 22.4 & 56.1 & 4.7 & 3.476 \\
\hline 4. & $\begin{array}{lr}\text { Policy } & \text { information, } \\
\text { confirmation and denial of } \\
\text { rumors or reports are } \\
\text { adequate } & \text { and } \\
\text { comprehensive. } & \end{array}$ & 107 & - & 18.7 & 36.4 & 36.4 & 8.4 & 3.345 \\
\hline 5. & $\begin{array}{lr}\text { Policy } & \text { information, } \\
\text { confirmation and denial of } \\
\text { rumors or reports } & \text { are } \\
\text { adequate } & \text { and }\end{array}$ & 107 & .9 & 10.3 & 33.6 & 48.6 & 6.5 & 3.495 \\
\hline
\end{tabular}


Law Enforcement in Malaysian Securities Markets

\begin{tabular}{|l|l|l|l|l|l|l|l|l|}
\hline & lomprehensive. & & & & & & & \\
\hline 6. & $\begin{array}{l}\text { Policy disclosure in } \\
\text { promotional activities to } \\
\text { excess is sufficient and } \\
\text { comprehensive. }\end{array}$ & 107 & - & 13.1 & 43.0 & 36.4 & 7.5 & 3.382 \\
\hline 7. & $\begin{array}{l}\text { Policy on insider trading is } \\
\text { sufficient and } \\
\text { comprehensive. } 107\end{array}$ & 1.9 & 13.1 & 34.6 & 44.9 & 5.6 & 3.392 \\
\hline 8. & $\begin{array}{l}\text { Regulations on disclosure } \\
\text { are adequate and } \\
\text { comprehensive periodic }\end{array}$ & 107 & - & 9.3 & 35.5 & 48.6 & 6.5 & 3.523 \\
\hline 9. & $\begin{array}{l}\text { Regulations pertaining to } \\
\text { the early preparation for } \\
\text { the announcement to the } \\
\text { public is sufficient and } \\
\text { comprehensive. }\end{array}$ & - & 9.3 & 27.1 & 57.0 & 6.5 & 3.607 \\
\hline
\end{tabular}

3. The relationship between the view and attitude of the Respondent on the Effective Implementation of Legal Philosophy Securities Commission and Bursa Malaysia

In addition to descriptive analysis made on data collected, this study also conducted a correlation analysis of the study variables. The correlation matrix is shown in Table 4 below. Table 4 below shows that there is a positive relationship between the views and attitudes of respondents in relation to the implementation of the legal philosophy of the effectiveness of the Securities Commission and Bursa Malaysia's performance of its functions and responsibilities as law enforcement agencies $(r=.524, r=480)$. In other words, the SC and Bursa Malaysia is seen to play their role effectively in accordance with the legal philosophy of the capital market in Malaysia.

Table 4: Correlation Matrix of Variables

\begin{tabular}{|c|c|c|c|c|c|c|c|c|c|}
\hline Variables & 1 & 2 & 3 & 4 & 5 & 6 & 7 & 8 & 9 \\
\hline Philosophy (1) & - & $.427 * *$ & $.524 * *$ & $.480 * *$ & $.311 * *$ & $.223 *$ & .173 & $.207 *$ & .107 \\
\hline Disclosure (2) & & - & $.360 * *$ & $.356 * *$ & .126 & $.276^{*}$ & .095 & .135 & $.328 * *$ \\
\hline SSM (3) & & & - & $.644 * *$ & $.571 * *$ & $.277^{*}$ & $.346 * *$ & $.234^{*}$ & .134 \\
\hline BM (4) & & & & - & $.457 * *$ & $.313^{* *}$ & .143 & .189 & .105 \\
\hline BM Policy(5) & & & & & - & .151 & $.253^{*}$ & .177 & .094 \\
\hline Crimes (6) & & & & & & - & $.423 * *$ & $.387 * *$ & $.346 * *$ \\
\hline Punishment (7) & & & & & & & - & .091 & $.290 *$ \\
\hline Civil Sanction(8) & & & & & & & & - & $.220 *$ \\
\hline Non compliance (9) & & & & & & & & & - \\
\hline
\end{tabular}

\section{Enforcement of law}

The success of Securities Commission in criminal prosecution in 2012, can be referred to the case Ashari Rahmat (Securities Commission, 2012) [16] where Ashari an operating Ashari, an operating officer of MIH, was charged in 2000 for engaging in an act which operated as a deceit on UPA Corporation Berhad's IPO exercise by switching successful applications with those not put through the balloting process. His conviction was confirmed and the fine sentence of RM1 million was ordered to be paid. The High Court also allowed a stay of the jail sentence pending appeal to the Court of Appeal upon payment of bail in the sum of RM500,000.

In 2011, in the case of Chan Kok Suan (Securities Commission, 2011) [17] , the Group Managing Director of Granasia Corporation Bhd, ("GCB"), was charged for causing to be submitted to SC false information, namely the revenue and profit after tax of GCB for the year ended 31 Dec 2002. This information was submitted in connection with GCB's listing proposal on the Main Board of the Exchange. The High Court Judge maintained the RM500,000.00 fine but increased the default of imprisonment from 10 months to 2 years. The prosecution has filed an appeal against the sentence to the Court of Appeal. In another case Mok Chin Fan, Jimmy Tok Soon Guan \& Cheong Kok Yai (Directors of Inix Technologies Holding Bhd) were charged with offences under s.122B(b)(bb) of the Securities Industry Act (SIA) for knowingly authorising the furnishing of false statements to Bursa in relation to Inix's 4 quarterly reports for FYE 31 July 2006; i.e. 31 Oct 2005, 31 Jan 2006, 30 April 2006 \& 31 July 2006. In addition they were charged under s.55(1)(a) of the Securities Commission Act (SCA) for causing the issuance of INIX Prospectus, which contained information that is false. Normah bt Sapar (Senior Account Executive of Inix) was charged with abetting Jimmy Tok in committing all the offences set out above. On 29 September 2011, Mok Chin Fan (Mok), Cheong Kok Yai (Cheong) and 
Normah binti Sapar (Normah) pleaded guilty to all the offences they were charged with. Jimmy Tok Soon Guan pleaded guilty to all the offences he was charged with on 13 October 2011. Mok and Cheong were each fined RM125,000 (in default 1 year imprisonment) for the offence under s.55 of the SCA and fined RM50,000 (in default 6 months imprisonment) for each of the four offences under s.122B of the SIA bringing the total fine imposed on Mok and Cheong to RM325,000. Normah was fined RM150,000 (in default 1 year imprisonment) for the offence under s.55 of the SCA and fined RM50,000 (in default 6 months imprisonment) for each of the four offences under s.122B of the SIA bringing the total fine imposed on Normah to RM350,000. Jimmy the CEO and Executive Director of INIX, was fined RM400,000 (in default 2 year imprisonment) for the offence under s.55 of the SCA. For the 4 offences under s.122B of the SIA, he was fined RM200,000 (in default 18 months imprisonment) for the first and second charges respectively and RM150,000 (in default 12 months imprisonment) for the third and fourth charge respectively bringing the total fine imposed on Jimmy to RM1.1 million.

In relation to civil actions and regulatory settlements the SC entered into a settlement with Lim Chin Chin (Securities Commission, 2012) [18] in the sum of RM232,320 when she agreed without admission or denial of liability to settle a claim that the SC was proposing to institute against her for insider trading in the shares of Sin Chew Media Corporation Berhad ('Sin Chew') between 29 January 2007 and 30 January 2007, contrary to Section 89E(3)(a) of the Securities Industry Act 1983. The settlement was reached following a letter of demand sent by the SC pursuant to its civil enforcement powers under the securities laws, where the sum Lim Chin Chin was required to disgorge was equivalent to three times the gains made by Ong Sew Teng and Chong Hiong Lim in connection with their trades in Sin Chew shares.

Sanctions were imposed for various breaches of the Bursa Malaysia Listing Requirements against listed issuers and their directors as shown in the table below. For 2008, the total number of sanctions issued was 160 and included reprimand and fines amounting to RM1,283,400.

Table 5: Enforcement by Bursa Malaysia

\begin{tabular}{|l||l|l|l|}
\hline Sanctions Imposed & Listed Issuers & Directors & Total \\
\hline Public Reprimand and Fine & 1 & 53 & 54 \\
\hline Public Reprimand & 49 & 17 & 66 \\
\hline Private Reprimand & 21 & 19 & 40 \\
\hline Total Sanctions & 71 & 89 & 160 \\
\hline Total Fines Imposed (RM) & 5,000 & $1,278,400$ & $1,283,400$ \\
\hline
\end{tabular}

(Source: Bursa Malaysia, 2012)

Enforcement actions were also instituted against market participants, their dealer representatives and agents for violation of Bursa Malaysia Rules. In 2008, a total of 127 enforcement actions were initiated and completed, with priority given to market offences. These actions encompass caution, reprimand, fines and suspension as presented in the table below and resulted in imposition of fines amounting to RM610,000. In order to enhance market awareness, the more severe breaches will be imposed public sanctions.

Table 6: Enforcement Actions by Bursa Malaysia

\begin{tabular}{|c|c|c|c|c|c|c|}
\hline $\begin{array}{l}\text { Type of Action } \\
\text { Taken }\end{array}$ & \begin{tabular}{|l} 
Participating \\
Organisations
\end{tabular} & $\begin{array}{l}\text { Authorised } \\
\text { Depository } \\
\text { Agents }\end{array}$ & $\begin{array}{l}\text { Derivatives } \\
\text { Trading } \\
\text { Participants }\end{array}$ & $\begin{array}{l}\text { Derivatives } \\
\text { Clearing } \\
\text { Participants }\end{array}$ & $\begin{array}{l}\text { Registered } \\
\text { Persons }\end{array}$ & Total \\
\hline Striking off & - & - & - & - & 1 & 1 \\
\hline Suspension & - & - & - & - & 1 & 1 \\
\hline $\begin{array}{l}\text { Reprimand \& } \\
\text { Fine }\end{array}$ & 5 & - & 4 & - & - & 9 \\
\hline Fine & 24 & 3 & 2 & - & 14 & 43 \\
\hline Reprimand & 20 & 9 & 1 & 5 & 12 & 47 \\
\hline Caution & 17 & 3 & 4 & - & 2 & 26 \\
\hline
\end{tabular}


Law Enforcement in Malaysian Securities Markets

\begin{tabular}{|l|l|l|l|l|l|l|}
\hline \hline $\begin{array}{l}\text { Total } \\
\text { Sanctions }\end{array}$ & 66 & 15 & 11 & 5 & 30 & 127 \\
\hline $\begin{array}{l}\text { Total Fines } \\
\begin{array}{l}\text { Imposed } \\
(\mathrm{RM})\end{array}\end{array}$ & 363,900 & 2,300 & 70,000 & - & 173,800 & 610,000 \\
\hline
\end{tabular}

(Source: Bursa Malaysia, 2012)

\section{CONCLUSION}

The overall findings of the study shows that respondents generally satisfied with the roles and responsibilities of enforcement bodies i.e. Securities Commission and Bursa Malaysia (mean of satisfaction = 3.660 to 3.952). Further, the study also shows that there is a positive relationship between the views and attitudes of respondents towards the implementation of the legal philosophy by the enforcement bodies ( $\mathrm{r}=.524$, $r=.480$ ). Even though the result is positive but as the main enforcement agencies, Securities Commission and Bursa Malaysia should further enhance efforts to monitor and enforce the law of capital markets. It is also proposed that courts should also play its role in imposing fines on criminals based on the amount of losses suffered by investors, severity and effects of crimes on markets stability. The courts should impose the maximum penalty rather than a moderate amount which is not justified the harm done to the markets and investors as a whole. More importantly, ethics training should be imposed to license holders by the Securities Commission. In conclusion, this paper provides useful information in relation to enforcement of law in Malaysian capital markets. It helps the enforcement body implemented measures on how to curb the unethical behaviour.

\section{Acknowledgements}

This research is financed by Fundamental Research Grant Scheme, Ministry of Higher Education, Malaysia.

\section{REFERENCES}

[1] Securities Commission, Law Enforcement by Securities Commission, Annual Report, Securities Commission, 2011. Available: http//www.sc.com.my (June 24, 2012)

[2] Securities Commission, Compliance with IOSCO principles, Securities Commission, 2008. Available: http//www.sc.com.my (June 24, 2012)

[3] International Organization of Securities Commission,The MMoU: Ten years of Enhancing Cross-border Enforcement Cooperation, Proc., The Annual Conference of the International Organization of Securities Commissions (IOSCO), Beijing, 2012 at pp 3.

[4] Securities Commission, Law Enforcement by Securities Commission, Annual Report, Securities Commission, 2011. Available: http//www.sc.com.my (June 24, 2012).

[5] Asmah Laili Yeon, Nurli Yaacob and Rohana Abd Rahman, Non compliance of public listed companies in Malaysia, research report, Universiti Utara Malaysia, Kedah, 2002. The research is financed by Universiti Utara Malaysia.

[6] Securities Commission, Corporate Governance Blueprint 2011, A Blue Print report, Securities Commission, 2011. Available: http//www.sc.com.my (June 24, 2012).

[7] Securities Commission, Capital Markets Plan 2, A Report, Securities Commission, 2011. Available: http//www.sc.com.my (June 24, 2012)

[8] International Law Books Services, Capital Markets and Services Act 2007 (Kuala Lumpur: ILBS, 2012).

[9] Securities Commission, Law Enforcement by Securities Commission, Annual Report, Securities Commission, 2011. Available: http//www.sc.com.my (June 24, 2012).

[10] International Law Books Services, Companies Act 1965 (Kuala Lumpur: ILBS, 2012).

[11] Securities Commission, Law Enforcement by Securities Commission, Annual Report, Securities Commission, 2011. Available: http//www.sc.com.my (June 24, 2012).

[12] Bursa Malaysia, Business Rules of Bursa Malaysia Securities Berhad (Market Misconduct) (Kuala Lumpur, 2011).

[13] Securities Commission, Law Enforcement by Securities Commission, Annual Report, Securities Commission, 2011. Available: http//www.sc.com.my (June 24, 2012).

[14] Bursa Malaysia, Listing Requirement of Public Listed Companies (Kuala Lumpur: Bursa Malaysia, 2012).

[15] Asmah Laili Yeon \& Faridahwati Mohd Shamsuddin, Pelaksanaan Kerangka Perundangan Penzahiran dalam pasaran Industri Sekuriti di kalangan pemegang-pemegang lesen di Malaysia. Research Report. Universiti Utara Malaysia, Kedah, 2011. The research is financed by Fundamental Research Grant Scheme, Ministry of Higher Education of Malaysia.

[16] Case Ashari Rahmat (2012). Enforcement of Securities Commission. Available at sc.com.my (June 24, 2012).

[17] Case Chan Kok Suan (2011). Enforcement of Securities Commission. Available at sc.com.my (June 24, 2012).

[18] Case Lim Chin Chin (2011). Enforcement of Securities Commission. Available at sc.com.my (June 24, 2012). 